\title{
MATHEMATICAL MODEL OF TERRITORIAL DEVELOPMENT OF MARINE OF UKRAINE AREAS UNDER THE BACKGROUND OF BIG DATA ${ }^{1}$
}

\author{
Liu Chang', Mamonov Kostiantyn ${ }^{2}$ \\ ${ }^{1}$ Institute of electronics and information engineering \\ Guangdong Ocean University \\ Street Haida 1, 524088, Zhanjiang City, Guangdong Province, PRC \\ ${ }^{2}$ O.M. Beketov National University of Urban Economy in Kharkiv \\ Marshala Bazhanova Str., 17, 61000, Kharkiv \\ byndgjc@163.com,kostia.mamonov2017@gmail.com
}

It is determined that one of the important directions in the formation of the territorial development of coastal regions of Ukraine is the increase in land use efficiency. To justify them, it is necessary to formulate a quantitative basis for decision-making on the use of mathematical tools to determine the relationships between factors affecting the territorial development of land use in coastal regions, which include spatial, urban, investment, and environmental factors. The aim of the study is to develop areas of mathematical modeling of the territorial development of land use in the coastal regions of Ukraine. To achieve this goal, the following tasks are solved: substantiation of the directions of mathematical modeling of territorial development of land use in the coastal regions of Ukraine; determination of the adequacy criteria for the developed mathematical models of the territorial development of land use in the coastal regions; interpretation of the results of mathematical modeling of the territorial development of land use in the coastal regions of Ukraine. The directions of mathematical modeling of the territorial development of land use in the coastal regions of Ukraine are proposed and substantiated. Mathematical modeling of the influence of spatial, urban, environmental and investment factors on the integral indicator of the territorial development of land use in the regions is carried out. Based on mathematical modeling, it is determined that at the present stage a moderate (balanced) scenario of the territorial development of land use is being implemented. However, this scenario does not provide permanent territorial development, increasing the efficiency of land use at the regional level. Based on mathematical modeling, it is proposed to develop practical scientifically-based recommendations for ensuring the territorial development of land use in regions by increasing spatial, urban, and investment factors. The need for further growth of environmental indicators of the territorial development of land use in the region is determined. Key words: territorial development, coastal regions of Ukraine, spatial, urban, environmental, investment factors, land use, an integral indicator of territorial development of land use in the regions.

Математичні моделі показників територіального розвитку приморських регіонів Украӥни. Лю Чан, Мамонов К.А.

Визначено, що одним із важливих напрямів формування територіального розвитку приморських регіонів України $\epsilon$ зростання ефективності використання земель. Для їх обгрунтування необхідно сформувати кількісну основу прийняття рішень із застосуванням математичного інструментарію, що дозволяє визначити зв'язки між чинниками, що впливають на територіальний розвиток використання земель приморських регіонів, які включають: просторові, містобудівні, інвестиційні та екологічні фактори. Метою дослідження є розробка напрямів математичного моделювання територіального розвитку використання земель приморських регіонів України. Для досягнення поставленої мети вирішуються такі завдання: обгрунтування напрямів математичного моделювання територіального розвитку використання земель приморських регіонів України; визначення критеріїв адекватності розроблених математичних моделей територіального розвитку використання земель приморських регіонів; інтерпретація отриманих результатів математичного моделювання територіального розвитку використання земель приморських регіонів України. Запропоновані та обгрунтовані напрями математичного моделювання територіального розвитку використання земель приморських регіонів України. Здійснено математичне моделювання впливу просторових, містобудівних, екологічних і інвестиційних чинників на інтегральний показник територіального розвитку використання земель регіонів. На основі математичного моделювання визначено, що на сучасному етапі реалізується помірний (збалансований) сценарій територіального розвитку використання земель. Проте цей сценарій не забезпечує перманентного територіального розвитку, підвищення ефективності використання земель на регіональному рівні. На основі математичного моделювання запропоновано розробити практичні науково-обгрунтовані рекомендації забезпечення територіального розвитку використання земель регіонів шляхом збільшення просторових, містобудівних, інвестиційних чинників. Визначена необхідність подальшого зростання екологічних показників територіального розвитку використання земель регіону. Ключові слова: територіальний розвиток, приморські регіони України, просторові, містобудівні, екологічні, інвестиційні чинники, використання земель, інтегральний показник територіального розвитку використання земель регіонів.

Formulation of the problem. One of the important directions in the formation of the territorial development of the coastal regions of Ukraine is the increase in land use efficiency. To justify them, it is necessary to form a quantitative basis for decision-making on the use of mathematical tools. It allows you to determine the relationship between factors affecting the territorial development of land use in coastal regions, which include: spatial, urban, investment and environmental factors.

${ }^{1}$ This arcitle is supported by the program for Guangdong Ocean University's «Innovation Strong School» in 2020 (230420023) and by the program for scientific research start-up funds of Guangdong Ocean University. 
Relevance of the research topic. The use of mathematical tools provides an opportunity to develop a quantitative basis for monitoring the use of land of the coastal regions of Ukraine and the formation of a quantitative basis for making informed decisions in the system of territorial development at the regional level, taking into account the peculiarities of land use in the coastal regions of Ukraine. Thus, the topic of the study to determine the possibilities and directions of using mathematical tools to ensure the territorial development of land use in the coastal regions is relevant and timely.

The connection of the author's refinement with important scientific and practical tasks is determined by the scientific provisions on the formation of territorial development at the regional level, the use of land and the application of modern areas of mathematical modeling. The practical significance of the study is characterized by the formation of areas for the efficient use of land in coastal regions and ensuring their territorial development.

Analysis of recent research and publications. The problems of territorial development of land use in regions are solved in scientific developments [1-the formation of spatial and information-analytical support for the territorial development of land use in coastal regions;

- determination of spatial, urban, environmental and investment factors affecting the territorial development of land use in coastal regions;

- development of mathematical models of the influence of spatial, urban, environmental and investment factors on the integral indicator of territorial development of land use in coastal regions;

- determination of the criteria for the adequacy of mathematical models of the influence of spatial, urban, environmental and investment factors on the integral indicator of the territorial development of land use in coastal regions;

- interpretation of the results.

To ensure the territorial development of land use in the regions, the formation of positive trends, given the influence of spatial, urban, investment and environmental factors, mathematical modeling tools are used, which are based on the method of correlation and regression analysis.

The study is carried out by applying information support on an integrated indicator of the territorial development of land use in the regions and spatial, urban, investment and environmental factors.

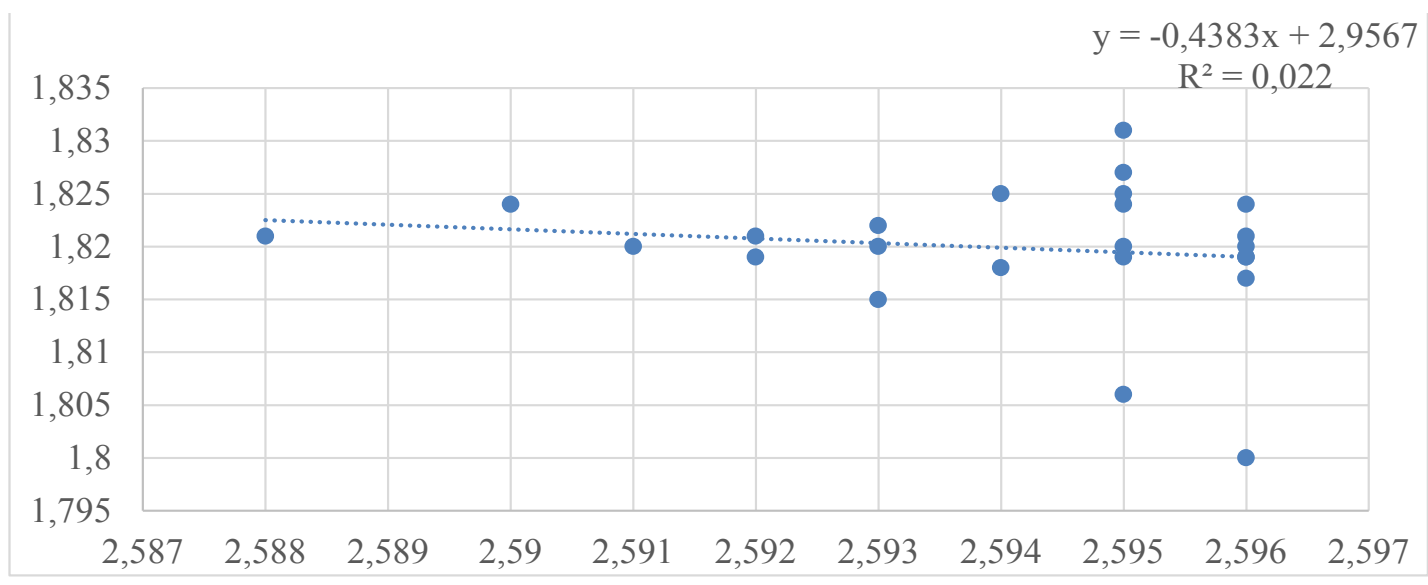

Fig. 1. The results of modeling the influence of spatial factors on the integral indicator of territorial development of land use in regions

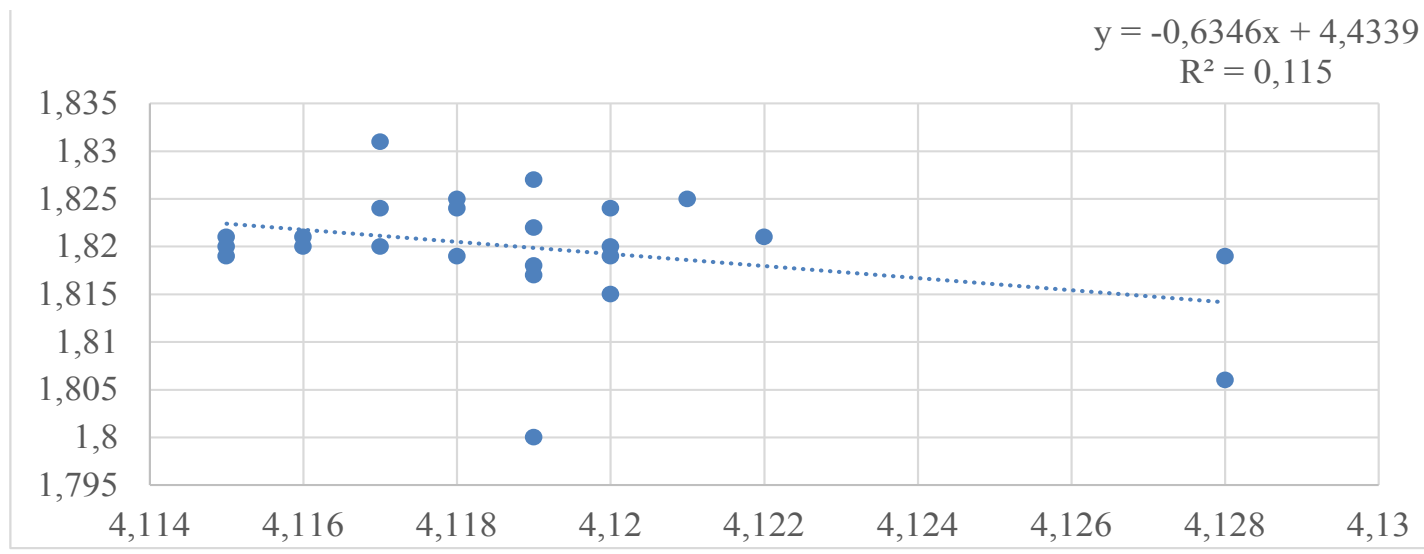

Fig. 2 The results of modeling the influence of urban factors on the integral indicator of territorial development of land use in the regions 


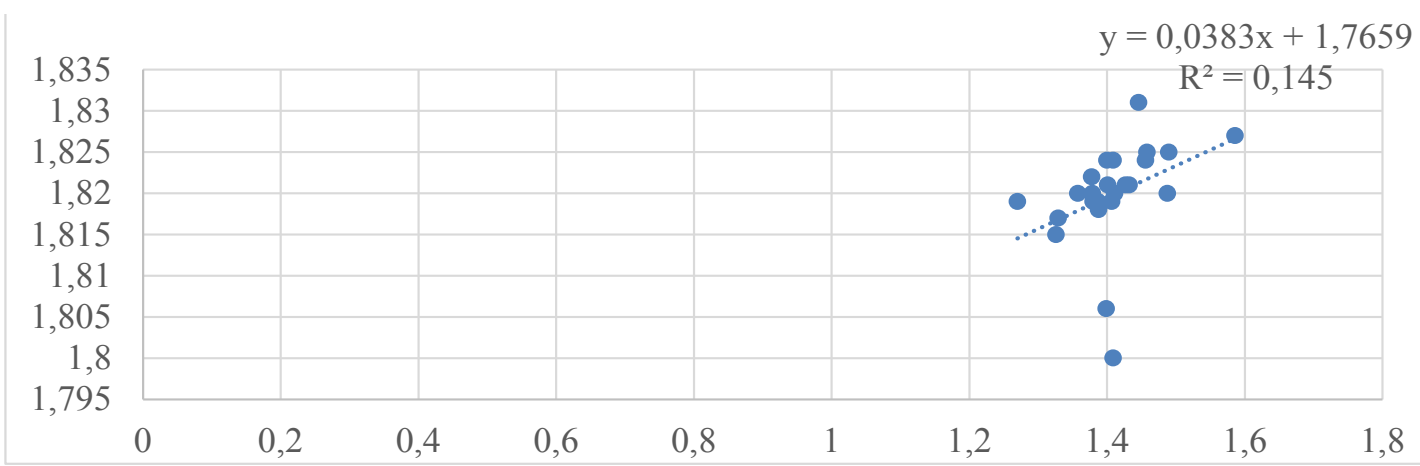

Fig. 3 The results of modeling the influence of investment factors on the integrated indicator of territorial development of land use in regions

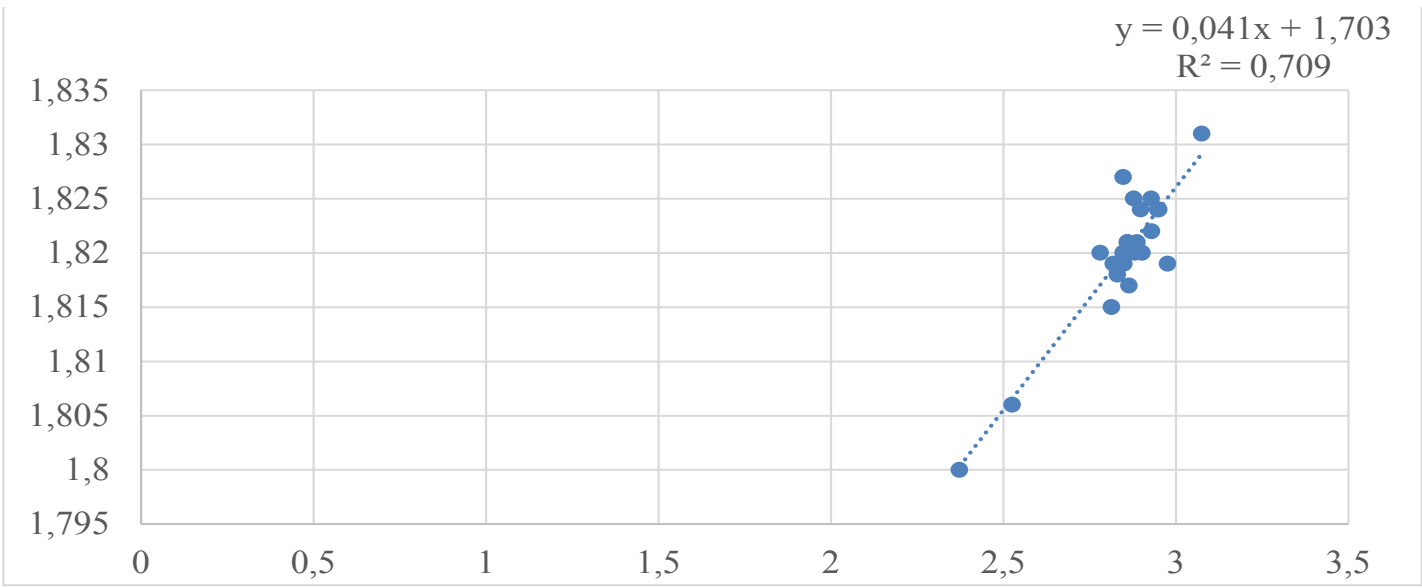

Fig. 4. The results of modeling the impact of environmental factors on the integrated indicator of territorial development of land use in regions

The results of modeling the influence of spatial factors on the integral indicator of territorial development of land use in regions are presented in Fig. 1.

The results of modeling the influence of urban factors on the integral indicator of territorial development of land use in the regions are presented in Fig. 2.

The model and degree of influence of investment factors on the integral indicator of territorial development of land use in the regions are presented in Fig. 3.

A mathematical model has been developed that characterizes the level of influence of environmental factors on the integral indicator of the territorial development of land use in regions presented in Fig. 4.

The degree of influence of spatial, urban, investment, and environmental factors on the integral indica- tor of territorial development of land use in regions is determined by the coefficient of determination, the value of which is presented in Table. 1.

As a result of modeling, a significant influence of the environmental factor on the integral indicator of territorial development of land use in the regions was determined. This is in line with current trends that are observed in the system of territorial development of regions, where the focus is on environmental areas and features, the implementation of environmental programs and the development of legislative support. The presented trends determine the development of developed international regional systems. It should be noted that in accordance with the value of the coefficient of determination, it can be argued that a $70.9 \%$

The values of the determination coefficients characterizing the level of influence of spatial, urban, investment and environmental factors on the integral indicator of the territorial development of land use in the regions, rel. Units (Developed by the author)

\begin{tabular}{|c|c|}
\hline Indicators & The value of the coefficient of determination $\left(\boldsymbol{R}^{2}\right)$ \\
\hline $\boldsymbol{T}_{1}$ & 0,022 \\
\hline $\boldsymbol{T}_{2}$ & 0,115 \\
\hline $\boldsymbol{T}_{3}$ & 0,145 \\
\hline $\boldsymbol{T}_{4}$ & 0,709 \\
\hline
\end{tabular}


increase in the generalizing environmental factor leads to a change in the integral indicator of territorial development of land use in the regions.

At a low level, the influence of investment and urban factors on the integral indicator of the territorial development of land use in the regions is determined. This is due to the fact that in modern conditions, the level of investment in the use of land in the regions is reduced, the amount of financing for land use measures is reduced or missing, the level of land valuation is reduced, unjustified development of settlements is carried out, the directions of their use are being changed, the quality and completeness of urban planning provision, identified the imbalance in the directions and features of the use of territories at the regional level. Thus, the influence of the investment and urban planning factors by 14.5 and $11.5 \%$ is responsible for changes in the integral indicator of territorial development of land use in the regions.

As a result of modeling, a low influence of the spatial factor on the integral indicator of the territorial development of land use in the regions was established. The spatial factor of only $2.2 \%$ causes changes in the integral indicator of territorial development. This indicates the absence of clear directions and the implementation of systemic measures aimed at creating spatial support for the territorial development of land use, information or geographic information systems are used at a low level, cartographic and topographic information is not updated comprehensively, the level of established boundaries of settlements is reduced, and there is no systematic financing of events creation and improvement of spatial support for land use and regional level, in full $\mathrm{n} e$ is performed regulatory support in the formation of the spatial ensure territorial development of land use.

Describing the developed models of the influence of spatial, urban, investment and environmental factors on the integral indicator of territorial development of land use in the regions, it is determined that the first two negatively affect the integral indicator. This indicates that spatial and urban factors in modern conditions hinder the territorial development of land use in the regions. Investment factors only form the potential investment attractiveness of the lands of the regions, however, measures to increase investment volumes are not implemented.

Environmental factors provide positive changes in the field of territorial development of land use at the regional level. The level of financing environmental measures and environmental safety is increasing, and the relevant areas are being systematically implemented. So, on the basis of mathematical modeling, it is determined that at the present stage a moderate (balanced) scenario of the territorial development of land use is being implemented. However, this scenario does not provide permanent territorial development, increasing the efficiency of land use at the regional level. The moderate scenario only "freezes" the existing situation, does not create conditions for further increase in the efficiency of land use in the coastal regions of Ukraine.

The main findings. Based on mathematical modeling, it is proposed to develop practical scientifically-based recommendations for ensuring the territorial development of land use in regions by increasing spatial, urban, and investment factors. The need for further growth of environmental indicators of the territorial development of land use in the region is determined. These measures will increase the integral indicator - as a generalized criterion for the effectiveness of land use at the regional level for the coastal territories of Ukraine.

Prospects for the use of research results. The results of the study can be applied in the territorial development system of the coastal regions of Ukraine to form a quantitative basis for making informed management decisions and develop appropriate measures to improve land use efficiency at the regional level.

\section{References}

1. Воскобійник М.В. Деякі питання правового регулювання земельних відносин у системі місцевого самоврядування. Проблеми удосконалення правового регулювання місцевого самоврядування в Украйні: матеріали наук.-практ. конф. Харків, 2004. С. 314-316.

2. Дорош О.С. Управління земельним ресурсами на регіональному рівні. Київ : ТОВ «ЦЗРУ», 2004. 142 с.

3. Лихогруд О.М. Наукові підходи до визначення цінності земельних ресурсів містобудівних систем у ринкових умовах. URL: http://www.agrosvit.info/pdf/6_2016/13.pdf/ (дата звернення: 04.04.2020).

4. Мамонов К.А. Міжнародний досвід забезпечення територіального розвитку використання земель регіону. Комунальне господарство міст. 2018. Вип. 146. С. 225-Мамонов К.А. Теоретичні підходи до визначення територіального розвитку використання земель регіону. Вчені записки Таврійського національного університету імені В. І. Вернадського. 2018. Том 29 (68) № 6. Ч. 2. С. 212-216.

5. Mamonov K. Methodological approach to the integral assessment of the regional lands use territorial development. Geodesy and Cartography. Vol. 45 (3) №. 2, 2019, pp. 110-115.

6. Мартин А.Г. Регулювання ринку земель в Україні : монографія. Київ : Аграр Медіа Груп, 2011. 254 с.

7. Палеха Ю.М. Теорія і практика визначення вартості територій і оцінки земель населених пунктів України (економіко-географічне дослідження) : автореф. дис... д-ра геогр. наук : 11.00.02. Київ, 2009. 40 с.

8. Larsson G. Land registration and Cadastral Systems: tools for land information and management. Esex: Longman Scientific and Technical, 1991. P. 387.

9. Williamson Ian, Stig Enemark, Jude Wallace, Abbas Rajabifard. Land administration for sustainable development. Esri Press. 2010, 506 p. URL: http://www.esri.com/landing-pages/industries/land-administration/e-book\#sthash. KF25CaWH.dpbs (дата звернення: 05.04.2020). 